\title{
Groundwater and River Interaction Impact to Aquifer System in Saigon River Basin, Vietnam
}

\author{
Tran Thanh Long ${ }^{\mathrm{a}}$ and Sucharit Koontanakulvong ${ }^{\mathrm{b}, *}$ \\ Department of Water Resources Engineering, Faculty of Engineering, Chulalongkorn University, 254 \\ Phayathai Road, Pathumwan, Bangkok 10330, Thailand \\ E-mail: attlongdcbk@yahoo.com, bsucharit.k@chula.ac.th (Corresponding author)
}

\begin{abstract}
Since the 1990s, under the pressure of socio-economic growth in the Ho Chi Minh City and nearby provinces, the heavy-extraction of groundwater of this area has dramatically increased to meet high water demand for domestic and industrial purposes. Although the groundwater - Saigon River interaction significantly contributes to groundwater reserves, researchers have been less attentive to fully describe and understand the river recharge. This study attempts to explore the impact of groundwater-river interaction to aquifer system due to pumping increase via field seepage and $\left(\mathrm{O}^{18}, \mathrm{H}^{2}\right)$ isotopic measurements in the Saigon River Basin, South East of Vietnam. The analysis showed that river bed conductance at $0 \mathrm{~km}, 30 \mathrm{~km}, 60 \mathrm{~km}$, $80 \mathrm{~km}$, and $120 \mathrm{~km}$ were $4.5 \mathrm{~m}^{2} /$ day $/ \mathrm{m}, 4.2 \mathrm{~m}^{2} /$ day $/ \mathrm{m}, 2.5 \mathrm{~m}^{2} /$ day $/ \mathrm{m}, 1.7 \mathrm{~m}^{2} /$ day $/ \mathrm{m}$, and $0.25 \mathrm{~m}^{2} /$ day $/ \mathrm{m}$ respectively. The riverbed conductance relies on the sand percentage of sediment. The composition $\delta \mathrm{O}^{18}$ in groundwater, river, and precipitation indicates that river recharge to groundwater exists mainly in the lower part of the basin. In contrast to downstream, the composition of $\delta \mathrm{O}^{18}$ was signified that the river primarily gains water from groundwater upstream. Under pressure of developing economies, the groundwater pumping in the Saigon river basin increased from $175,000 \mathrm{~m}^{3} /$ day in 1995 to $880,000 \mathrm{~m}^{3} /$ day in 2017 . As a consequence of the increased pumping rate, the groundwater discharge to the river decreases from 1.6 to 0.7 times of groundwater pumping in upstream, while the amount of Saigon river recharge increases by $33 \%$ to $50 \%$ of the total groundwater pumping downstream. Under the exceedance pumping rate, the aquifers in the Saigon River Basin release less water to the Saigon river and it tends to gain more water through the river groundwater interaction process. Therefore, groundwater management in downstream aquifers needs better joint planning with surface water development plans, particularly for surface water supply utilities which still struggle to satisfy the water demand of the development plan.
\end{abstract}

Keywords: Groundwater-river interaction parameters, stable isotope, Saigon River.

ENGINEERING JOURNAL Volume 24 Issue 5

Received 15 May 2019

Accepted 16 July 2020

Published 30 September 2020

Online at https:/ / engj.org/

DOI:10.4186/ej.2020.24.5.15 


\section{Introduction}

The river fluxes to aquifer systems are a significant component to estimate the potential long-term yield of groundwater from those systems [1-4]. Since the 1980s, numerous researchers have developed many methods to estimate the fluxes exchange as well as river-groundwater interaction parameters: quantify the rate of river gain and loss through small cross-section riverbed via seepage meters [5-7], i.e., to estimate flows in and out at streambed utilizing measurement piezometric head differences between the river and the subsurface flow via streambed piezometers $[5,8-10]$ and to identify possible groundwater recharge sites obtained the isotopic characterization of rainfall, surface water, and groundwater [11, 12]. Somehow, the nonlinear interactions among river recharge-discharge into aquifers remain challenge tasks on direct measurement and distribution spatial variability for long-term on a regional scale. In addition, despite recent advancements in numerical modeling, the complexity of surface water and groundwater interaction parameters probably drive to inappropriate estimated groundwater storage. The lithological composition of streambeds and aquifers mostly are considered as static, homogeneous entities. [13]. Thus, the simplified conceptualization of complex surface watergroundwater interactions also produces uncertainty inputs for the hydrogeology process $[14,15]$. Henceforth, the estimated system parameters without a perception of the groundwater-river interaction mechanism may bring inappropriate inputs into groundwater model solutions, especially in an alluvial plain area [16].

Since the 1990s, under the pressure of social and economic growth in the Ho Chi Minh City and nearby provinces, the excessive groundwater extraction has caused aquifers to be dramatically drawn down, resulting in critical groundwater shortages downstream [17, 18]. In order to preserve groundwater resources in Saigon River, numerous publications attempted to investigate groundwater resources in the Saigon River basin. In 2000, Win Boehmer [19] developed conductance values for all hydraulic stations of the river system by utilizing hydraulic conductivity from pumping tests in the Nambo Plain, including the Saigon River Basin. The calculated conductance in the Saigon River is from $2.2 \mathrm{~m} /$ day to $4.4 \mathrm{~m} /$ day. In 2010, Chân and Kỳ [20] and Khai [21] assessed potential groundwater recharge via inverse numerical groundwater modeling. The groundwater-river interaction parameters were followed by the conductance values of Win Boehmer [19]. The results indicated that the river recharge contributes $20 \%$ to $40 \%$ of the groundwater budget in the Saigon River Basin. Moreover, the river recharge amount has a linear relationship with groundwater abstraction. Tuan and Koontanakulvong [22] developed a function of interaction parameters for the middle part of the Saigon River via the piezometric head. However, most studies focused on the hydraulic conductivity of aquifers without considering sediment riverbed properties and evaluating the ratio between land recharge and river recharge.

In order to have more robust groundwater resources planning for sustainable socio-economic development, the groundwater recharge mechanism must be explored more intensively under transient conditions. The aim of this study is to derive interaction parameters, to understand groundwater and river interaction impacts on the aquifer system in the Saigon River basin, Vietnam. First, interaction parameters along the Saigon River basin were confirmed via piezometric head and field seepage measurements. Second, the seasonal water balance of river-groundwater was evaluated in 5 sections by utilizing $\left(\mathrm{O}^{18}, \mathrm{H}^{2}\right)$ isotopic. Finally, by comparing the signatures, it is possible to understand the interaction groundwatersurface water impact on the aquifers system.

\section{Background, Procedures, and Theories Used}

\subsection{Background and Study Area}

The area of Saigon River Basin comprises of a total area of $6,640 \mathrm{~km}^{2}$ located between latitudes $10.320 \mathrm{E}$ to 11.201 E and longitudes $106.215 \mathrm{~N}$ to $107.024 \mathrm{~N}$. (Fig. 1). The study domain experiences a tropical climate, particularly a tropical wet and dry climate, with an average humidity of $75 \%$. There are two distinct seasons in a year: the rainy season from May to October and the dry season from Nov to April. The mean annual rainfall amounts to $1,612 \mathrm{~mm}$ and means annual temperature to $27^{\circ} \mathrm{C}$. The topography of the area varies from $0 \mathrm{~m}$. MSL to $70 \mathrm{~m}$. MSL. The Saigon river originates in Cambodia. In Vietnam, it passes through the Dautieng Dam in Tay Ninh Province, Binh Phuoc Province, Binh Duong Province, and Hochiminh City before flowing into the sea. The Saigon river stretches $280 \mathrm{~km}$ from the Dautieng Dam to estuary. At $60 \mathrm{~km}$ from the Dautieng Dam, the Saigon river distinguishes in 2 parts: the upper reach with $100 \mathrm{~m}$ wide and $12 \mathrm{~m}$ water depth and the lower reach including 225 to $370 \mathrm{~m}$ width and up to $24 \mathrm{~m}$ water depth (Fig. $1 \mathrm{a}$ ). The storage capacity of the Dau Tieng reservoir is from 470 (at the dead water level of $17 \mathrm{~m}$ ) to 1.68 billion $\mathrm{m}^{3}$ at the normal operating water level of $24.4 \mathrm{~m}$, whose functions are flood control and irrigation for agricultural production in Ho Chi Minh City region. Moreover, the reservoir simultaneously assumes the role of controlling a salinity of $4 \%$ at Phu An station (downstream of the Saigon River) during the drought period [23]. This study focused on the impact of groundwater and river interaction on the fresh aquifers in Saigon River Basin, Vietnam excluding the potential areas of salt intrusion movement and seawater rise impacts. The groundwater model area covers from dam release location till Phu An station as shown in the dashed line in Fig 1 a). 


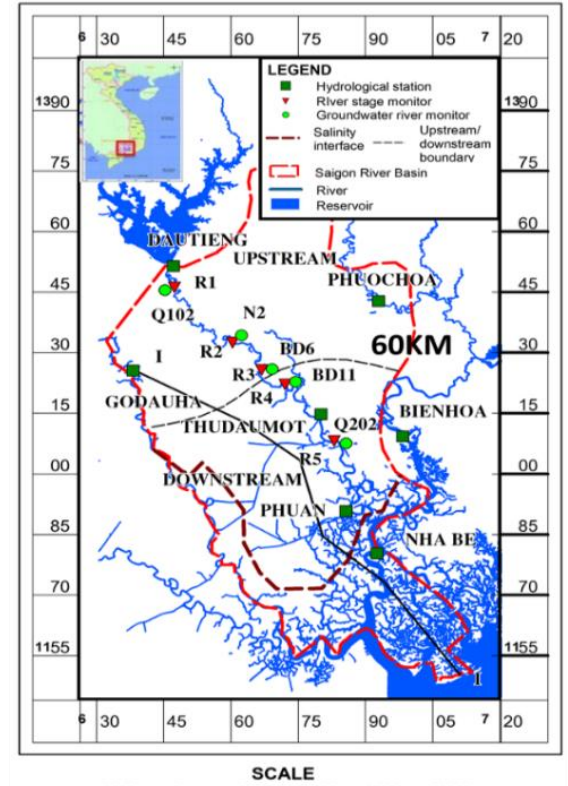

$15000 \quad 0 m \quad \begin{gathered}\text { SCALE } \\ 15000 \quad 30000 \quad 45000 \quad 60000\end{gathered}$

a)

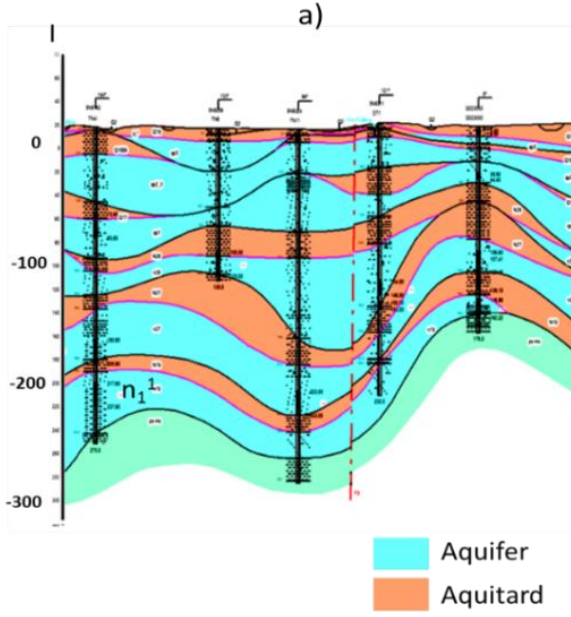

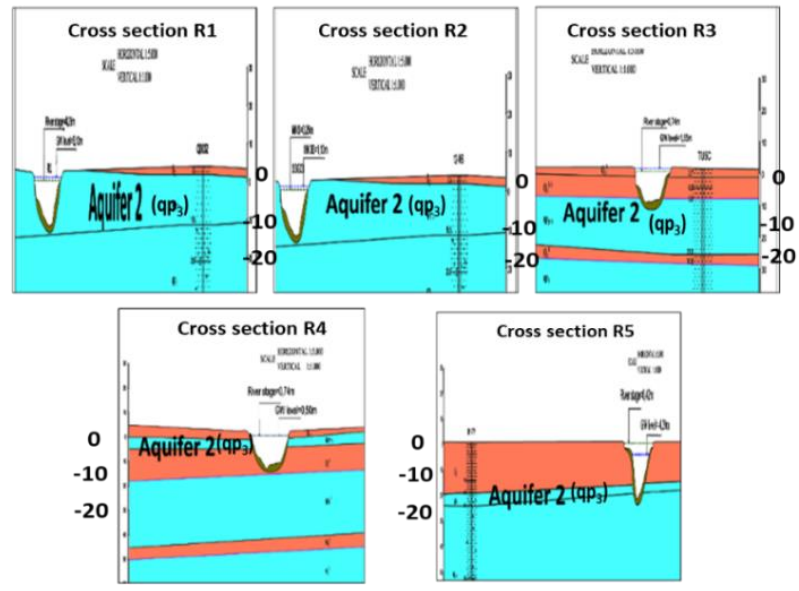

b)

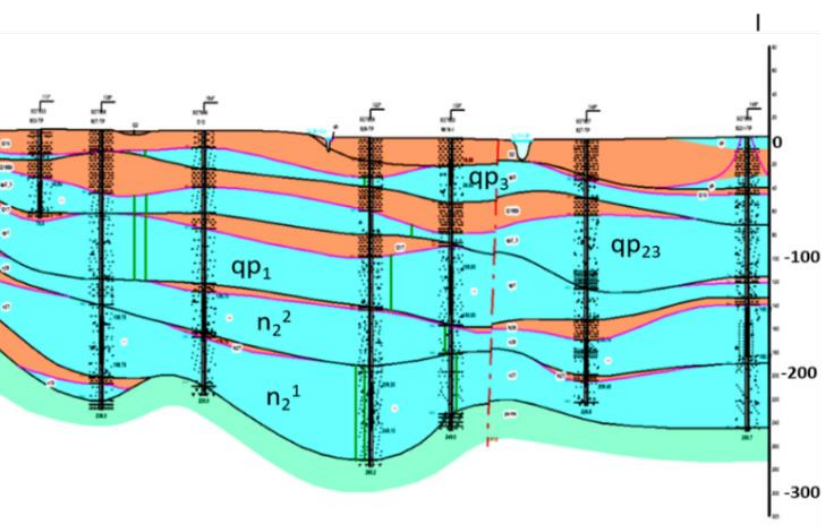

| Borehole I Fault

c)

Fig. 1. Location map (a), Seepage measurement cross-section(b) and Hydrogeology cross-section in the study area (c) $[24,25]$.

Saigon River Basin has six confined aquifers consisting of alluvial sediments. Each aquifer is separated from the others by clay layers (Fig. 1b [24]). The aquifers were named according to the formation sequence, from the uppermost to the lowest, as follows: the Upper Pleistocene aquifer ( $\mathrm{qp}_{3}$ ), with an average thickness of 23 $\mathrm{m}$; the Upper-Middle Pleistocene aquifer (qp2-3), with an average thickness of $27 \mathrm{~m}$; the Lower Pleistocene aquifer (qp 1 ), with an average thickness of $27 \mathrm{~m}$; the Upper Pliocene aquifer $\left(\mathrm{n}_{2}{ }^{2}\right)$, with an average thickness of $38 \mathrm{~m}$; the Lower Pliocene aquifer $\left(\mathrm{n}_{2}{ }^{1}\right)$, with an average thickness of $34 \mathrm{~m}$. Based on a TDS cutoff of $1,000 \mathrm{mg} / \mathrm{L}$ [26], groundwater in the study area could be divided into two groups: the central and the northern areas, exhibited TDS concentrations of $<1,000 \mathrm{mg} / \mathrm{L}$, corresponding to freshwater, whereas the southern area, and part of the western area, had higher TDS concentrations corresponding to saline water (Fig. 1a [24, 25]). After 23 years of rapidly increased abstraction, groundwater levels in all aquifers have been declined by 12 meters in the upper Pleistocene aquifer and by 40 meters in the lower Pleistocene aquifer. Currently, groundwater pumping volume in Saigon River Basin was estimated at 880,000 $\mathrm{m}^{3} /$ day $[25,27]$, of which $484,000 \mathrm{~m}^{3} /$ day and 396,000 $\mathrm{m}^{3} /$ day were used for domestic activities (residents, public works and services) and industry, respectively $[25,28]$.

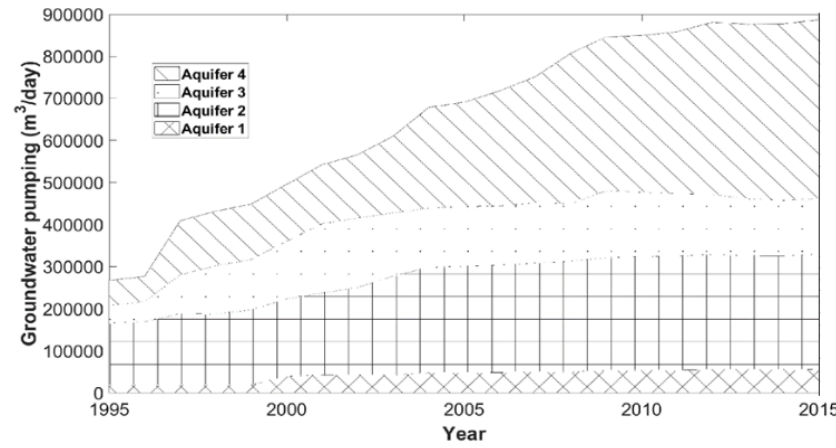

Fig. 2. Groundwater pumping in Saigon River Basin [25, 27]. 
Regarding hydrogeology cross-section [25, 29], the upper-Pleistocene (qpa: aquifer 1), and Upper Middle Pleistocene ( $\mathrm{qp}_{2-3}$ : aquifer 2 ) interact with Saigon river from Dautieng dam to Phu An. Moreover, the piezometer heads of both aquifers oscillated with fluctuation of the Saigon river stage (Fig. 8). Therefore, this study only focused on the interaction between the Saigon river and Pleistocene aquifers due to the availability of leakage from the river to aquifers. Our results provide information essential for an effective management plan to protect and preserve the groundwater resource.

\subsection{Procedures}

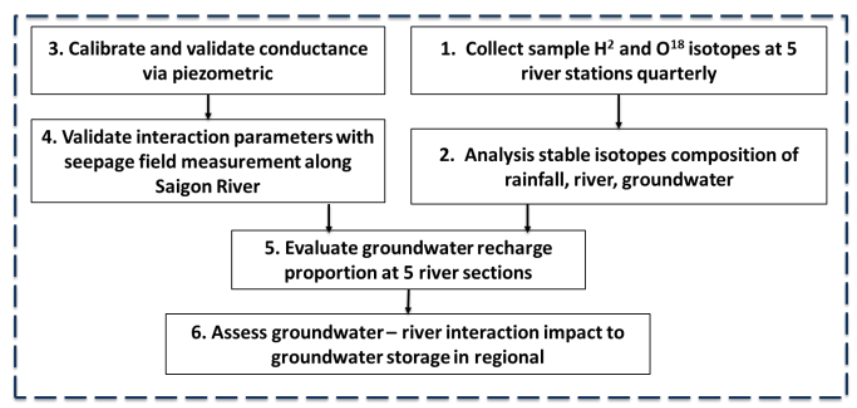

Fig. 3. Study Procedures.

To understand the river - groundwater interaction in Saigon River Basin, the impact assessment procedure in the study comprises of 6 steps: (1) Collect sample $\mathrm{H}^{3}$ and $\mathrm{O}^{18}$ isotope at 5 river stations quarterly; (2) Analyze stable isotopes composition of rainfall, river, groundwater; (3) Calibrate and validate river bed conductance along Saigon river via piezometric head; (4) Develop groundwater modeling and validate interaction parameters with five seepage measurements along Saigon River; (5) Evaluate groundwater recharge at 5 river sections via oxygen -18 ; (6) Assess groundwater-river interaction impact to groundwater storage in regional scale. The overall study procedure is shown in Fig. 3.

To develop groundwater systems in Saigon River Basin, the boundary condition of aquifers modeling used average monthly observed piezometric heads surrounding the Saigon River Basin. The land recharge rate was applied by multi effective rainfall with a recharge ratio as Long [30]. Water levels along rivers were established using an average monthly of monitored river stage. The pumping rate and hydrogeology parameters were extracted from the hydrogeology map data of Vuong [25]. The grid size of modeling is $1 \mathrm{~km} \times 1 \mathrm{~km}$. The simulation duration is from the year 1995 to 2017. To investigate the characteristics of river bed conductance, the field seepage measurement was conducted and compared with parameters from inverse groundwater modeling along the Saigon River Basin. In order to evaluate groundwater recharge composition, stable isotope samples of groundwater, river, and rainfall were collected at 5 sections (as Fig. 1b) quarterly in the year 2018.

\subsection{Theories Used}

\section{Groundwater model}

Aquifer storage change to natural and human-induced stresses is simulated using a groundwater flow model, with a piezometric head (groundwater level) and fluxes into and out of an aquifer as model parameters. The governing equation of the three-dimensional movement of groundwater is

$$
\frac{\delta}{\delta \mathrm{x}}\left[\mathrm{K}_{\mathrm{xx}} \frac{\delta \mathrm{h}}{\delta \mathrm{x}}\right]+\frac{\delta}{\delta \mathrm{y}}\left[\mathrm{K}_{\mathrm{yy}} \frac{\delta \mathrm{h}}{\delta \mathrm{y}}\right]+\frac{\delta}{\delta \mathrm{z}}\left[\mathrm{K}_{\mathrm{zz}} \frac{\delta \mathrm{h}}{\delta \mathrm{z}}\right]+\mathrm{W}=\mathrm{S}_{\mathrm{s}} \frac{\delta \mathrm{h}}{\delta \mathrm{t}}
$$

where the hydraulic conductivity along the $\mathrm{x}, \mathrm{y}$, and $\mathrm{z}$ coordinate axes $(\mathrm{m} / \mathrm{da})$ are $\mathrm{K}_{\mathrm{xx}}, \mathrm{K}_{\mathrm{yy}}$, and $\mathrm{K}_{\mathrm{zz}}$, respectively, and $\mathrm{h}$ is the potentiometric head (groundwater level) (m/day),

The volumetric flux per unit volume of sources and/or sinks of water is denoted by W, where water exploitation results in negative values and injections/recharge as positive. $\mathrm{W}$ is to be considered a function of space and time (i.e. $\mathrm{W}=\mathrm{W}(\mathrm{x}, \mathrm{y}, \mathrm{z}, \mathrm{t})$ ), $\mathrm{S}_{\mathrm{s}}$ is the porous material's specific storage as a function of space,

$\mathrm{t}$ is time (day).

\section{River bed conductance}

The Darcy approach is a common method for quantifying the exchange of flow between groundwater and surface water, specifically on large pond or basin scale. The gradients and exchange water flow between the wells and the surface-water body are calculated via the measurements of water levels in wells near the river and measurements of river water stages. The formulas describe as follows:

$$
\begin{gathered}
\mathrm{Q}=\mathrm{C}\left(\mathrm{h}_{1}-\mathrm{h}_{2}\right) \\
\mathrm{C}=\frac{\mathrm{K}^{*} \mathrm{~A}}{\mathrm{~L}}=\mathrm{K} \frac{\mathrm{w}}{\mathrm{t}}
\end{gathered}
$$

Q is the volumetric flow ( $\mathrm{m}^{3} /$ day),

$\mathrm{C}$ is river bed conductance $\left(\mathrm{m}^{2} /\right.$ day $\left./ \mathrm{m}\right)$,

$\mathrm{K}$ is the hydraulic conductivity of the material in the riverbed ( $\mathrm{m} /$ day),

A is the cross-sectional area perpendicular to the flow $\left(\mathrm{m}^{2}\right)$,

$\mathrm{h}_{1}$ is the head of the river $(\mathrm{m})$,

$\mathrm{h}_{2}$ is the head of the aquifer to flow (m),

$\mathrm{L}$ is the length of the prism parallel to the flow path (m), $t$ is the thickness of the sediment in the bottom of the river (m),

$\mathrm{w}$ is the width of the material along the length of the arc (m). 
In addition, the river bed conductance can be measured via seepage measurement, a device commonly used to directly measure the water flux across the sediment-water interface [31]

$$
\mathrm{C}=\frac{\mathrm{Q} * \Delta \mathrm{z} * \mathrm{~W}}{\mathrm{~A}_{\mathrm{b} *} \Delta \mathrm{h}}
$$

where $\mathrm{Q}$ is the flow rate, which can be measured by seepage meters $\left(\mathrm{m}^{3} /\right.$ day),

$\Delta z$ is the thickness of sediments (m),

$\Delta \mathrm{h}$ is the difference piezometers ( $\mathrm{m})$, $\left(\mathrm{m}^{2}\right)$,

$A_{b}$ is the cross-section area of seepage meters

$\mathrm{w}$ is the width of the cross-section river (m). better understanding the river - groundwater interaction process, the proportion of river charge and land recharge was analyzed through the use of a concentration of stable isotope. The analyst for simple two-component mixing model is applied as [7]:

$$
\mathrm{Q}_{\mathrm{GW}} \delta_{\mathrm{GW}}=\mathrm{Q}_{S} \delta_{\mathrm{S}}+\mathrm{Q}_{\mathrm{P}} \delta_{\mathrm{P}}
$$

where $\mathrm{Q}$ is volume discharge,

$\delta$ is the stable-isotopic composition in parts per thousand enrichment or depletion ("per mil") relative to a standard,

$\mathrm{S}$ is stream water,

GW is groundwater, $\mathrm{P}$ is precipitation.

\section{Mass balance of isotopic compositions of groundwater}

The groundwater resources of the Saigon river basin were dominated by land recharge and Saigo river. For

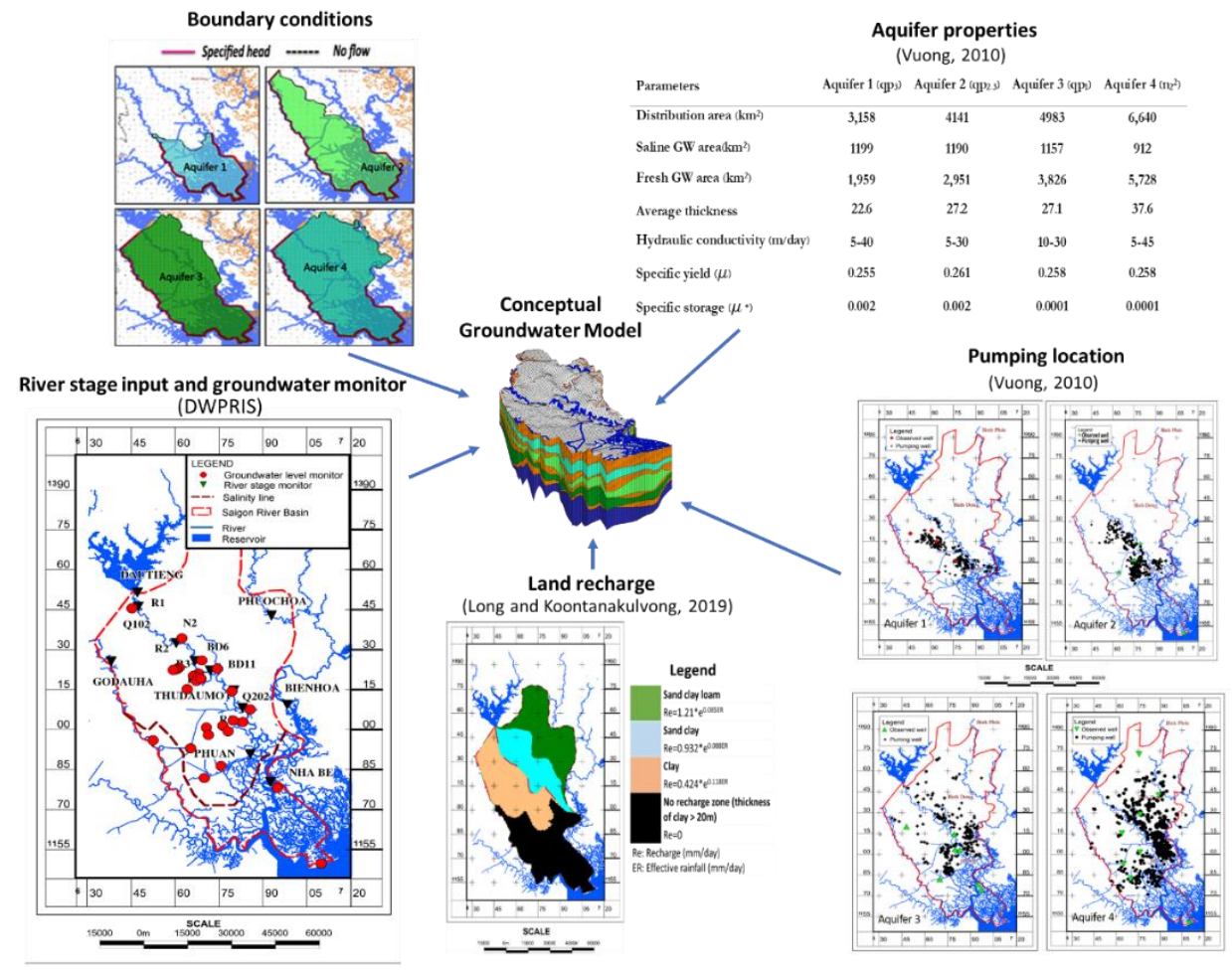

Fig. 4. Conceptual groundwater model and inputs in the study.

\section{Conceptual groundwater model}

Figure 4 presented the conceptual groundwater modeling for the Saigon River aquifers system. The boundary conditions of the study area include no-flow, specified head, general head. In the interface of mountain areas and at the places perpendicular to the groundwater flow direction, the boundary is defined as a "no-flow" boundary as they are impermeable boundaries [32]. Along the constraint line of the study area, the boundary of aquifers is defined as a "specific head" boundary. The specified head was set from average monthly observed piezometric heads surrounding Saigon River Basin. The aquifer properties utilized from the hydrology map [24]. Since the groundwater use comes from domestics and industries, the groundwater pumping in the dry season was set as same as in the wet season. The locations of observed wells and pumping wells are collected from the Division for Water Resources Planning and Investigation for the South of Viet Nam [24]. To limit the rate of saline intrusion movement into freshwater areas, the pumping well in Saigon River Basin mainly allocated distant from 
the saline boundary. Moreover, the hydraulic gradient line of the saline boundary is stable for 23 years pumping.

\section{Results and Discussions}

\subsection{Groundwater - River Interaction Parameters}

First, from groundwater modeling, the conductance coefficient was estimated via inverse modeling at 5 sections which named R1-Q102, R2-N2, R3-BD06, R4BD11, R5-Q202 (as Fig. 1a). The model calibration and verification depended on good statistical performance between computed piezometric to observe piezometric heads at 5 wells named: Q102; N2; BD06; BD11; Q202 (as in Table 1). The sample of calibration and validation conductance presents in Fig.5. The mean errors range from 0.07 meters to 0.61 meters. The maximum errors are from 0.37 meters to 2.5 meters. The R-squared are in the ranges of 0.6-0.86. Moreover, the simulation values are in the confidence interval range of observation data (see example in Fig. 6). This suggests that the overall performance of the model is fairly good. Therefore, the conductance parameters are able to apply for the further river - groundwater interaction analysis.

Table 1. Statistics performance of calibration and verification.

\begin{tabular}{|c|c|c|c|c|c|c|c|c|c|c|}
\hline Section name & $\begin{array}{l}\text { R1 - } \\
\text { Q102 }\end{array}$ & $\begin{array}{l}\text { R2 - } \\
\text { N2 }\end{array}$ & $\begin{array}{c}\text { R3 - } \\
\text { BD06 }\end{array}$ & $\begin{array}{l}\text { R4 - } \\
\text { BD11 }\end{array}$ & $\begin{array}{c}\text { R5 - } \\
\text { Q202 }\end{array}$ & $\begin{array}{l}\text { R1 - } \\
\text { Q102 }\end{array}$ & $\begin{array}{l}\text { R2 - } \\
\text { N2 }\end{array}$ & $\begin{array}{c}\text { R3 - } \\
\text { BD06 }\end{array}$ & $\begin{array}{c}\text { R4 - } \\
\text { BD11 }\end{array}$ & $\begin{array}{l}\text { R5 - } \\
\text { Q202 }\end{array}$ \\
\hline & \multicolumn{5}{|c|}{ Calibration (1995 - 2006) } & \multicolumn{5}{|c|}{ Verification (2007-2017) } \\
\hline Max Error (m) & 1.73 & 0.15 & 2.5 & 0.37 & 1.99 & 1.78 & 0.28 & 0.68 & 0.58 & 1.22 \\
\hline Min Error (m) & 0 & 0.04 & 0.04 & 0 & 0 & 0.01 & 0.03 & 0 & 0.02 & 0 \\
\hline Mean Error (m) & 0.61 & 0.12 & 0.1 & 0.12 & 0.02 & 0.16 & 0.11 & 0.06 & 0.05 & 0.07 \\
\hline $\mathrm{R}^{2}$ & 0.86 & 0.94 & 0.68 & 0.72 & 0.65 & 0.83 & 0.79 & 0.6 & 0.7 & 0.57 \\
\hline $\begin{array}{l}\text { Conductance } \\
\left(\mathrm{m}^{2} / \text { day } / \mathrm{m}\right)\end{array}$ & 4.5 & 4.2 & 2.5 & 1.7 & 0.25 & 4.5 & 4.2 & 2.5 & 1.7 & 0.25 \\
\hline
\end{tabular}

Second, the computed riverbed conductance was validated with the seepage field measurements along the river during August and October 2018. The results from field seepage measurements are shown in Fig. 6. The value near the dam is from $4 \mathrm{~m}^{2} / \mathrm{d} / \mathrm{m}$ to $6 \mathrm{~m}^{2} / \mathrm{d} / \mathrm{m}$. The value at $35 \mathrm{~km}$ ranges $3.2-4.7 \mathrm{~m}^{2} / \mathrm{d} / \mathrm{m}$. At $60 \mathrm{~km}$, the riverbed conductance varies from $2.1 \mathrm{~m}^{2} / \mathrm{d} / \mathrm{m}$ to $2.9 \mathrm{~m}^{2} / \mathrm{d} / \mathrm{m}$. At $80 \mathrm{~km}$, the measured values are in the range of 1.2-1.7 $\mathrm{m}^{2} / \mathrm{d} / \mathrm{m}$. At $120 \mathrm{~km}$, the riverbed conductance measures $0.25 \mathrm{~m}^{2} / \mathrm{d} / \mathrm{m}$. Hence, the estimated riverbed conductance

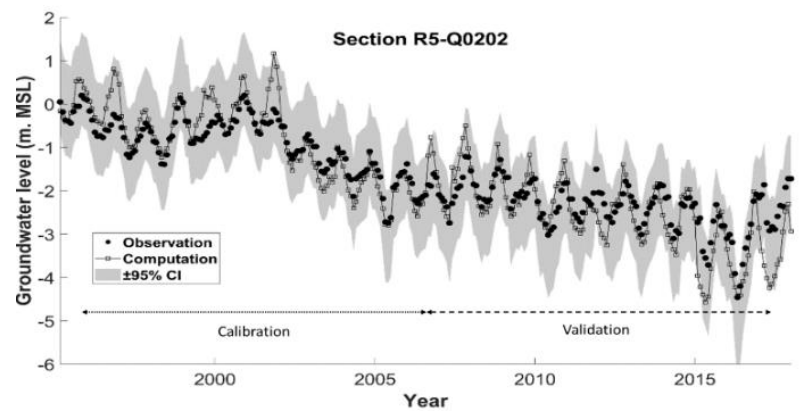

Fig. 5. Sample of calibration and verification result. by modeling agrees with the seepage field measurement (Fig. 6). In addition, the soil test analysis reveals the proportion of sand-sized sediment tends to decrease along the river (see Fig. 6). The change in sediment properties along the river implies that Saigon River's lithological sediments are the direct consequence of the decreasing conductance from upstream to downstream.

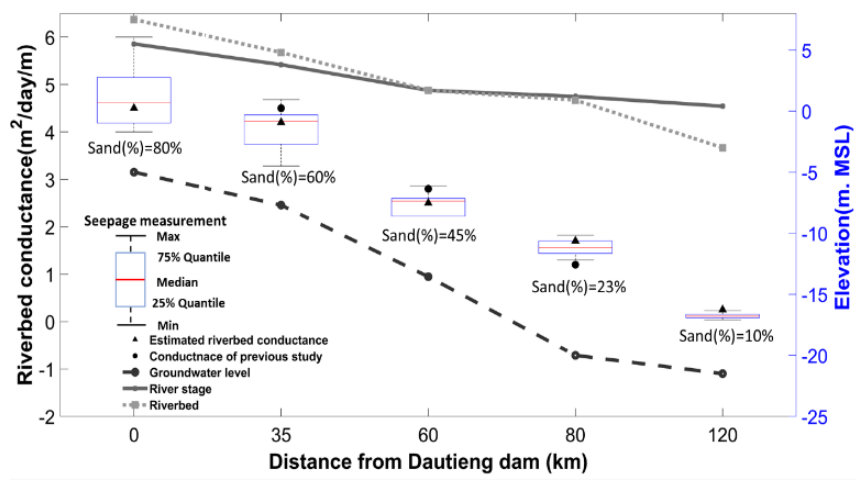

Fig. 6. Groundwater - river interaction parameters and river bed soil type along the Saigon river $(\bullet$ previous study - Tuan and Koontanakulvong [22]). 


\subsection{Quantifying Water Recharge Budget by $\mathrm{O}^{18}$}

To qualify the exchange fluxes of the river into groundwater, the isotope analysis from rain, well and river water samplings were conducted quarterly in year 2018. As shown in Fig. 7, there exists a good correspondence between the hydrogen and oxygen isotope compositions obtained from the groundwater sample of the observation wells and to those of along the Saigon River. The $\delta \mathrm{O}^{18}$ and $\delta \mathrm{H}^{2}$ isotopic sample of groundwater collected at five stations vary between $-7.4 \% 0$ and $-5.5 \% 0$ and $-46.3 \% 0$ and $-38.2 \%$, respectively. The river consisted of $\delta \mathrm{O}^{18}$ from $-7 \%$ to $-5.5 \%$ and $\delta \mathrm{H}^{2}$ from $-47 \%$ to $-39 \%$. Meteoric Water Line was built from isotopic samples of Hochiminh City precipitation. The $\delta \mathrm{O}^{18}$ of precipitation varies from $-8.89 \%$ to $-6.57 \%$, while $\delta \mathrm{H}^{2}$ are in range $53.79 \%$ to $-32.16 \%$. In general, the slope isotopic of groundwater, river, precipitation distinguished in three different lines. The isotopic composition of groundwater is in line with the river's upstream and downstream. The collected isotope samples of groundwater and Saigon River water in the upstream exhibit similarity isotopic composition. This shows that the groundwater and river in the upstream would be from the same origin. Also, the groundwater level above the river stage in upstream drives groundwater leakage along the riverbank (see Fig. 8). Therefore, the groundwater mainly discharges to Saigon
River in the upstream. Contrarywise, the $\delta \mathrm{O}^{18}$ of groundwater is lower than the $\delta \mathrm{O}^{18}$ of the river but higher than the $\delta \mathrm{O}^{18}$ of rainfall in downstream. Besides, the fluctuating groundwater level corresponds with the river stage and rainfall event. The groundwater level also below the river stage downstream (see Fig. 8). With the above evidence, it concluded that groundwater in downstream was dominated by mixing sources of land recharge and Saigon river.

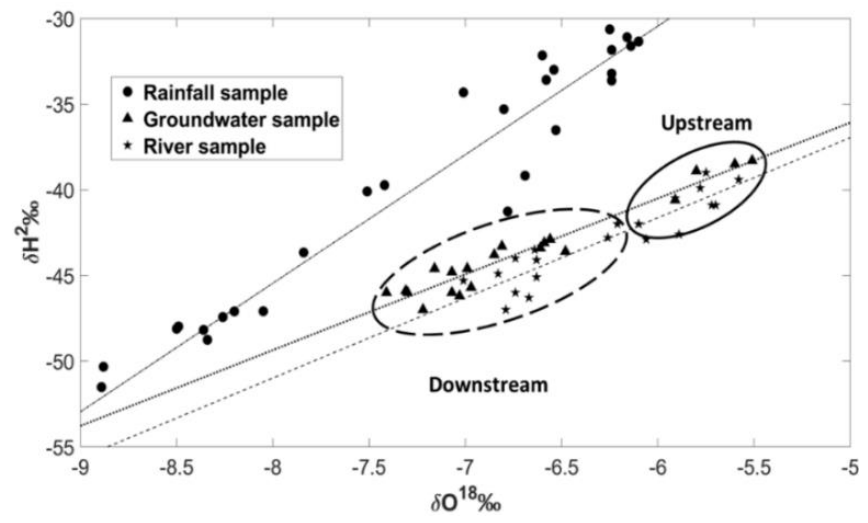

Fig. 7. The relationship between $\delta \mathrm{H}^{2}$ and $\delta \mathrm{O}^{18}$ of groundwater sample, river sample, rainfall sample in Saigon River Basin.

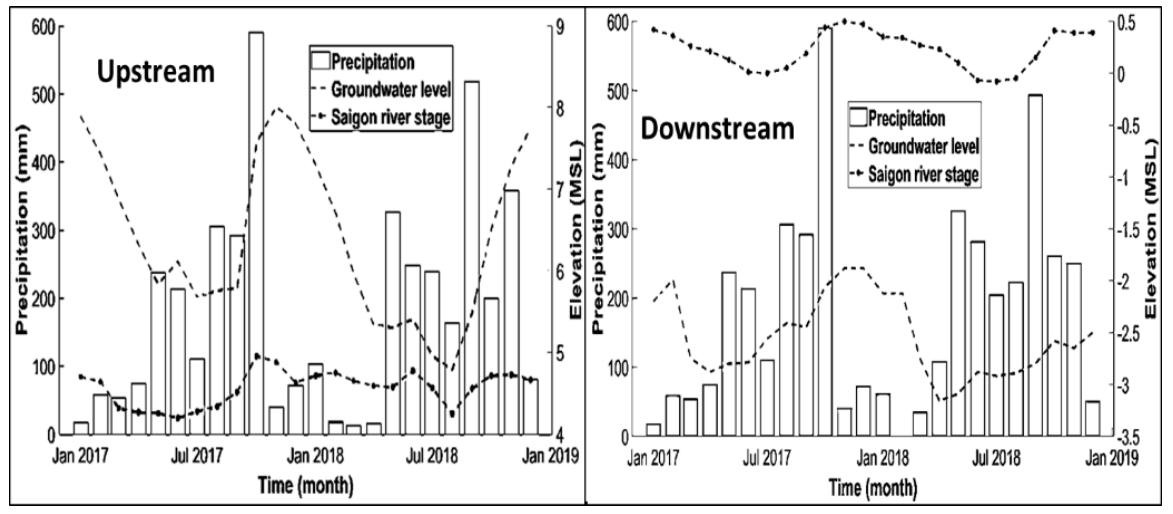

Fig. 8. Groundwater level, Saigon river stage, and precipitation in Saigon River Basin.

Table 2. Comparison of isotope composition and fluxes recharge from modeling.

\begin{tabular}{lcccccc}
\hline & Distance & \multicolumn{3}{c}{ Isotope } & \multicolumn{2}{c}{ Groundwater modeling } \\
\cline { 3 - 7 } $\begin{array}{c}\text { Name } \\
\text { fection }\end{array}$ & $\begin{array}{c}\text { from } \\
\text { Dautieng } \\
\text { dam }\end{array}$ & GW $(\%)$ & $\begin{array}{c}\text { Land } \\
\text { recharge } \\
(\%)\end{array}$ & $\begin{array}{c}\text { River } \\
\text { recharge } \\
(\%)\end{array}$ & $\begin{array}{c}\text { Land } \\
\text { recharge } \\
\left(\mathrm{m}^{3} / \text { day }\right)\end{array}$ & $\begin{array}{c}\text { River } \\
\text { recharge } \\
\left(\mathrm{m}^{3} / \text { day }\right)\end{array}$ \\
\hline R1-Q202A & $0 \mathrm{~km}$ & 100 & 0 & 100 & $336(100 \%)$ & $0(0 \%)$ \\
R2-N2 & $35 \mathrm{~km}$ & 100 & 86 & 14 & $336(100 \%)$ & $0(0 \%)$ \\
R3-BD6 & $60 \mathrm{~km}$ & 100 & 69 & 31 & $148(70 \%)$ & $64(30 \%)$ \\
R4-BD11 & $80 \mathrm{~km}$ & 100 & 61 & 39 & $148(64 \%)$ & $83(36 \%)$ \\
R5-Q102A & $120 \mathrm{~km}$ & 100 & 27 & 73 & $268(23 \%)$ & $874(77 \%)$ \\
\hline
\end{tabular}

In order to correctly understand how groundwater recharges, it was essential to assess the actual recharge of groundwater by rainfall and river water. The ratio between land recharge and river recharge from isotope analysis showed agreement with exchange fluxes in Saigon regional groundwater model (see Table 2). At the distance $0 \mathrm{~km}$, the water from the groundwater with an enriched isotopic signature is mainly discharged source to the Saigon river. Since the distance $36 \mathrm{~km}$, the composition $\delta \mathrm{O}^{18}$ in surface water and groundwater indicated that river water accounted for $14 \%-73 \%$ of the total groundwater recharge. While the land recharge archived $27 \%-86 \%$ of total groundwater recharge. The percentage of river recharge gradually increase from distance $60-\mathrm{km}$ to 120 $\mathrm{km}$. Because of the intensive pumping rate downstream, the declining groundwater level below the river level. It drives the river recharge to aquifers to complement the groundwater storage. According to Saigon regional groundwater modeling, the land recharge at five field workstations varies $148-336 \mathrm{~m}^{3} /$ day, while the river recharge range $-1005-874 \mathrm{~m}^{3} /$ day. Regarding river groundwater interaction evidence above, Saigon River 
Basin could be divided at $60 \mathrm{~km}$ distance from the Dautieng Dam into two parts: the upstream where the groundwater absorbs land recharge and release to the Saigon river, and the downstream where the river significantly dominated to groundwater recharge.

\subsection{Groundwater - River Interaction Impact to Aquifers System due to Pumping Increase}

Figure 9 illustrate the impact of river interaction on to aquifer system due to pumping increase towards drawdown at Saigon River Basin during 1995-2017. Due to the pumping pattern in the downstream Saigon river basin, the water budget can be divided into 3 periods: low pumping from 1995 to 2000, increasing pumping during 2001 -2010, and maintain high pumping since 2011 until now. For the low pumping period, the groundwater storage in upstream is high (100 million $\mathrm{m}^{3} /$ year). In upstream, the groundwater discharged to the river is 1.6 times of groundwater pumping. In downstream, the groundwater storage is positive during the low pumping period. The river recharge in downstream contributes $33 \%$ volume for groundwater pumping. Under pressure of developing economies from 2001 to 2010, groundwater pumping started to exceed the total groundwater recharge in downstream. Aftereffect, hydraulic head have progressively declined in downstream Saigon River Basin. Thus, the gap between river and groundwater has been enlarged in recent years, which inadvertently enhanced the

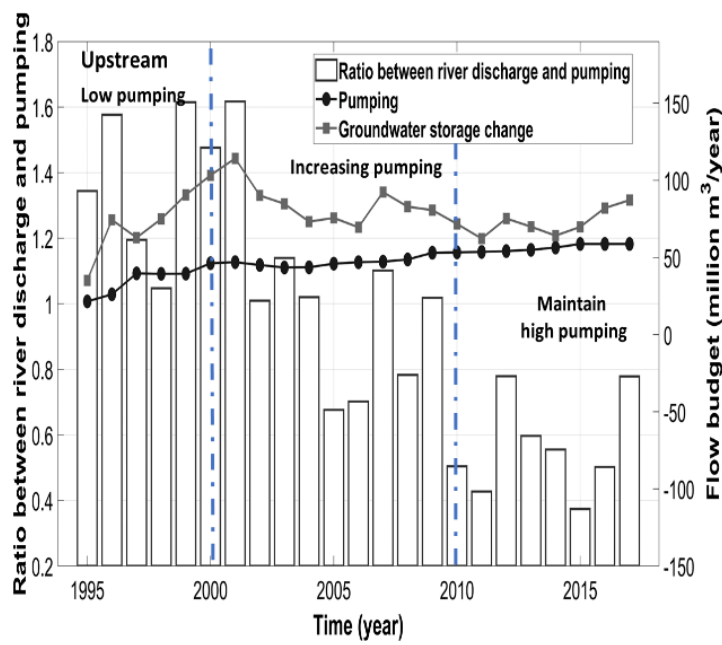

Saigon river recharge process into the aquifer system. The ratio between river recharge and pumping rate downstream reach 0.47 in year 2010. However, the river recharge is insufficient to balance the increasing pumpage during this period. Hence, groundwater storage and groundwater levels at downstream Saigon River Basin have been dramatically fallen. Likewise, groundwater storage upstream and groundwater discharge to the river slightly reduce. The groundwater discharge to the river decrease from 1.6 times to 0.6 times of groundwater pumping. Not surprisingly, since the groundwater level downstream is lower than the Saigon river stage, the groundwater upstream tends to divert flow direction to aquifers downstream instead of the Saigon river. Since 2011, the groundwater abstraction in Saigon River Basin retained a high pumping rate $\left(\sim 880,000 \mathrm{~m}^{3} /\right.$ day $)$. The Saigon river continues supplying $40-50 \%$ amount of the total groundwater pumping downstream. The groundwater storage downstream become stable in recent years. Meanwhile, in the upstream, the groundwater storage and the groundwater discharge to the Saigon river marginally decrease. The groundwater discharge to the river in recent years equals 0.2 to 0.7 times of groundwater pumping. Under the exceedance pumping rate, the groundwater not only gains more the flux from the downstream Saigon river but also release less water to the upstream Saigon river. Therefore, the river - groundwater interaction plays a vital supply source for groundwater reserves in the Saigon River Basin.

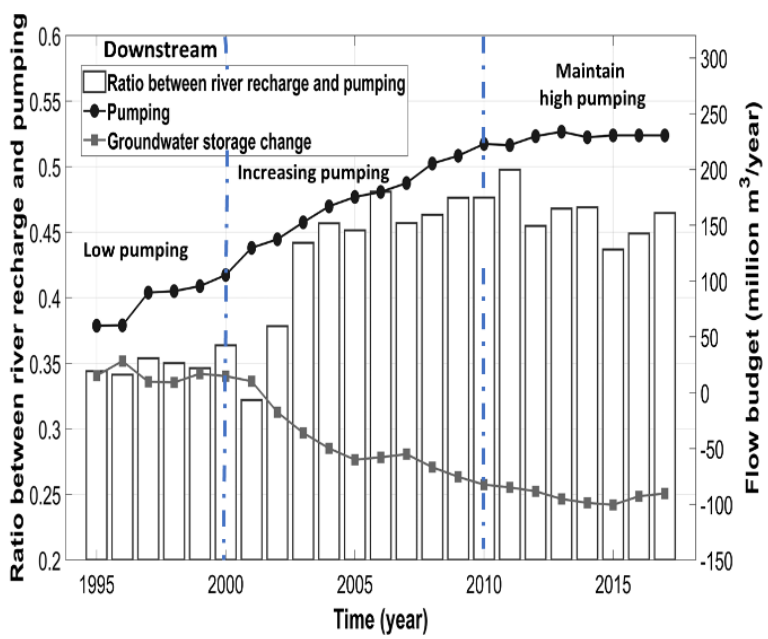

Fig. 9. The impact of river interaction to aquifer system due to pumping towards drawdown at Saigon River Basin.

\section{Conclusions}

The groundwater-river interaction parameters were evaluated via field measurements and invert groundwater modeling. The conductance values at $0 \mathrm{~km}, 30 \mathrm{~km}, 60 \mathrm{~km}$, $80 \mathrm{~km}$, and $120 \mathrm{~km}$ are $4.5 \mathrm{~m}^{2} / \mathrm{day} / \mathrm{m}, 4.2 \mathrm{~m}^{2} / \mathrm{day} / \mathrm{m}, 2.5$ $\mathrm{m}^{2} /$ day $/ \mathrm{m}, \quad 1.7 \mathrm{~m}^{2} /$ day $/ \mathrm{m}$, and $0.25 \mathrm{~m}^{2} /$ day $/ \mathrm{m}$, respectively. The conductance values derived reduce from upstream to downstream in accordance with riverbed materials which changed from sand in the upstream to silt in the downstream.
The exchange fluxes of the river into groundwater was qualified via the stable isotope sampled of groundwater, river, rainfall. The results indicate that the groundwater discharge to the river upstream and gain recharge from the river downstream. The river recharge percentage increases from upstream to downstream.

Under pressure of developing economies, the groundwater pumping in the Saigon river basin increased from $175,000 \mathrm{~m}^{3} /$ day in 1995 to $850,000 \mathrm{~m}^{3} /$ day in 2017 . Because of the growing pumping rate, the river groundwater interaction flux has been impacted and altered in both upstream and downstream. The 
groundwater discharge to the river decreases from 1.6 to 0.7 times of groundwater pumping in upstream. The amount of Saigon river recharge increases by $33 \%$ to $50 \%$ of the total groundwater pumping downstream. To balance the high groundwater abstraction, the aquifers system in Saigon River Basin tends to release less water to the Saigon river and to gain more water through the river - groundwater interaction process.

Thus, aquifer management in downstream area will require good coupling with river water plan, especially HCMC surface water supply expansion works, an area which has not fulfilled the rapid increase of water demand.

\section{Acknowledgment}

This research was supported by a Ph.D. sandwich program scholarship from AUN - Seednet and the Water Resources System Research Unit of Faculty of Engineering, Chulalongkorn University. The authors would also like to show our gratitude to the staff at Division for Water Resources Planning and Investigation for the South of Vietnam, Southern Regional Hydrometeorology Center Department of Resources and Environmental, Center for Nuclear Techniques in Ho Chi Minh City for data collection.

\section{References}

[1] D. N. Lerner, "Identifying and quantifying urban recharge: a review," Hydrogeology journal, vol. 10, no. 1, pp. 143-152, 2002.

[2] M. Sophocleous, "Interactions between groundwater and surface water: the state of the science," (in English), Hydrogeology Journal, vol. 10, no. 1, pp. 5267, 2002/02/01 2002.

[3] D. Allen, D. Mackie, and M. J. H. J. Wei, "Groundwater and climate change: a sensitivity analysis for the Grand Forks aquifer, southern British Columbia, Canada," vol. 12, no. 3, pp. 270290, 2004.

[4] S. Koontanakulvong and P. Siripubttichaikul, "Determination of recharge rate from soil classification map in GW modelling," in 17. World congress of soil science, Bangkok (Thailand), 14-21 Aug 2002.

[5] D. R. Lee and J. A. Cherry, "A field exercise on groundwater flow using seepage meters and minipiezometers," Journal of Geological Education, vol. 27, no. 1, pp. 6-10, 1979.

[6] L. C. Murdoch and S. E. Kelly, "Factors affecting the performance of conventional seepage meters," Water Resources Research, vol. 39, no. 6, 2003.

[7] D. O. Rosenberry and J. W. LaBaugh, "Field techniques for estimating water fluxes between surface water and ground water," Geological Survey (US)2328-7055, 2008.

[8] C. Schmidt, B. Conant Jr, M. Bayer-Raich, and M. J. J. o. H. Schirmer, 'Evaluation and field-scale application of an analytical method to quantify groundwater discharge using mapped streambed temperatures," vol. 347, no. 3-4, pp. 292-307, 2007.

[9] R. M. Fanelli and L. K. J. G. Lautz, "Patterns of water, heat, and solute flux through streambeds around small dams," vol. 46, no. 5, pp. 671-687, 2008.

[10] J. R. Barlow and R. H. J. W. R. R. Coupe, "Use of heat to estimate streambed fluxes during extreme hydrologic events," vol. 45, no. 1, 2009.

[11] O. A. E. Abdalla, T. Al-Hosni, A. Al-Rawahi, A. Kacimov, and I. Clark, "Coupling isotopic and piezometric data to infer groundwater recharge mechanisms in arid areas: example of Samail Catchment, Oman," Hydrogeology Journal, journal article, vol. 26, no. 8, pp. 2561-2573, December 012018.

[12] J. González-Trinidad, A. Pacheco-Guerrero, H. Júnez-Ferreira, C. Bautista-Capetillo, and A. J. W. Hernández-Antonio, "Identifying Groundwater Recharge Sites through Environmental Stable Isotopes in an Alluvial Aquifer," vol. 9, no. 8, p. 569, 2017.

[13] D. Partington, R. Therrien, C. T. Simmons, and P. J. R. o. G. Brunner, "Blueprint for a coupled model of sedimentology, hydrology, and hydrogeology in streambeds," vol. 55, no. 2, pp. 287-309, 2017.

[14] K. i. Kosugi, M. Fujimoto, S. y. Katsura, H. Kato, Y. Sando, and T. Mizuyama, "Localized bedrock aquifer distribution explains discharge from a headwater catchment," vol. 47, no. 7, 2011.

[15] P. Brunner, R. Therrien, P. Renard, C. T. Simmons, and H. J. Hendricks Franssen, "Advances in understanding river-groundwater interactions," Reviews of Geophysics, 2017.

[16] W. Sanford, "Recharge and groundwater models: an overview," Hydrogeology journal, vol. 10, no. 1, pp. 110120, 2002.

[17] V. L. Phu, "Formulation of an integrated approach to sustainable water management in Ho Chi Minh City, Vietnam," Thesis (Ph.D.), School of Social Sciences: Geographical and Environmental Studies, The University of Adelaide, Adelaide, South Australia, 2008.

[18] N. D. Chan, "Water Resources Planning in Binh Duong Province,' Division for Water Resources Planning and Investigation for the South of Viet Nam, Report 2015.

[19] Win Boehmer, "Surface water data and processing for the hydrogeological model of the Mekong delta," Haskoning B. V. Consulting Engineers and Architects in association with Division for Water Resources Planning and Investigation for the South of Viet Nam2000.

[20] N. Đ. Chân and N. V. Kỳ, "Originating source of groundwater reserve in Saigon river basin," Vietnam Journal of Earth Sciences, vol. 32, no. 4, pp. 326-334, 2010.

[21] H. Q. Khai, "Impact of Climate Change on groundwater recharge in Ho Chi Minh City Area," Chulalongkorn University, 2014. 
[22] P. V. Tuan and S. Koontanakulvong, "Groundwater and River Interaction Parameter Estimation in Saigon River, Vietnam," Engineering Journal, vol. 22, no. 1, pp. 257-267, 2018.

[23] N. Dan, N. Ha, B. Than, N. Nga, and L. Khoa, "Sustainable groundwater management in Asian Cities: a final report of research on sustainable water management policy, water resources management in Ho Chi Minh City," Institute for Global Environmental Strategies (IGES), pp. 68-79, 2007.

[24] B. T. Vuong, "Hydrogeological and Engineering Geological Maps on the Scale of 1/50,000 of Ho Chi Minh City," Division for Water Resources Planning and Investigation for the South of Vietnam, Division for Water Resources Planning and Investigation for the South of Vietnam2010.

[25] B. T. Vuong and P. N. Long, "Groundwater Environment in Ho Chi Minh City, Vietnam," in Groundwater Environment in Asian Cities: Elsevier, 2016, pp. 287-315.

[26] R. A. Freeze, and Cherry, J.A., Groundwater. Englewood Cliffs, NJ, Prentice-Hall, 1979, p. 604.

[27] Department of Natural Resources and Environment of Binh Duong province (DNRE-Binh Duong), "Master plan water resources in Binh Duong in 2016-2025, a vision to 2035," Department of Natural Resources and Environment of Binh Duong province 2017.
[28] N. Nga, "State of groundwater management in HCM city The 5th Research meeting on the sustainable water management policy," Hochiminh city 2006.

[29] Division for Water Resources Planning And Investigation For The South Of Viet Nam (DWPRIS), "Results of Local Real Survey Determining Current Situation Of Water Resources Under The Exploitation And Use; Problems Of Landscape, Landscape, Loss, Loss Of Water Responsible By Exploiting Underground Water," Division for Water Resources Planning And Investigation For The South Of Viet Nam,2016.

[30] T. T. Long and S. Koontanakulvong, "Deep Percolation Charactertistics via Soil Moisture Sensor Approach In Saigon River Basin, Vietnam," International Journal of Civil Engineering \& Technology (IJCIET) - Scopus Indexed, vol. 10, no. 03, p. 10, 2019.

[31] S. E. Kelly and L. C. Murdoch, "Measuring the hydraulic conductivity of shallow submerged sediments," Groundwater, vol. 41, no. 4, pp. 431-439, 2003.

[32] S. Qiu, X. Liang, C. Xiao, H. Huang, Z. Fang, and F. J. W. Lv, "Numerical simulation of groundwater flow in a river valley basin in Jilin Urban area, China," vol. 7, no. 10, pp. 5768-5787, 2015.

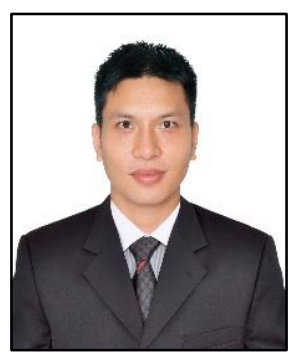

Tran Thanh Long First was born in Hochiminh, Vietnam in 1988. He received the B.S. degrees in Geology and Petroleum engineering from the Hochiminh City University of Technology, Hochiminh City, Vietnam, in 2012, the M.S and the Ph.D. degree in Water Resources Engineering from Chulalongkorn University, Bangkok, Thailand in 2014 and in 2020.

Hid research interests include groundwater - surface water interaction, groundwater recharge, impact climate change.

Dr. Tran was a recipient of the Scholarship for ASEAN Students at Chulalongkorn Universityin 2012, and the Doctoral degree sandwich programs AUN-seed net 2016.

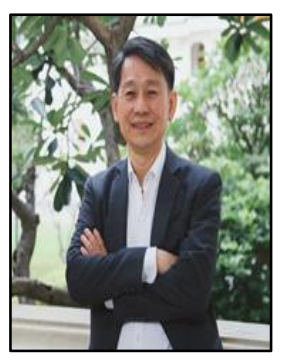

Sucharit Koontanakulvong was born in Bangkok, Thailand in 1955. He received his B.S, MS and $\mathrm{PhD}$ degree in water use engineeing from Kyoto University, Japan in 1983.

$\mathrm{He}$ is an Associate Professor of Water Resources Engineering at Chulalongkorn University, Thailand. His research interests are in the field of hydrology, water resources planning including climate change impact assessment and adaptation. He has published more than 40 papers in peerreviewed international journal and presented more than 40 conference papers ranging from hydrological modeling, groundwater modeling t climate impact and vulnerability assessment.

He is assigned as an UNESCO Chair on Water and Disaster Management and Climate Change from 2016 and has been awarded PAWEES 2014 International Awards from the International Society of Paddy and Water Environment Engineering, Sak Intania Awards from Faculty of Engineering, Chulalongkorn University. He is also assigned to be a Program Chair on Spearhead Research on Water Resources Management from National Research Council of Thailand from 2019. 